\title{
Yhdeksäsluokkalaisten vieraan kielen oppimismotivaatioprofiilien ja arvosanan yhteydet peruskoulun jälkeisiin jatkosuunnitelmiin
}

\author{
Teija Kangasvieri, Jyväskylän yliopisto
}

\begin{abstract}
Tässä artikkelissa tarkastelen peruskoulun yhdeksännen luokan oppilaiden vieraan kielen oppimismotivaatioprofiilien ja kieltenopetuksessa saatujen arvosanojen yhteyttä heidän perusopetuksen jälkeisiin jatko-opiskelusuunnitelmiinsa. Tutkimuksen tavoitteena on tarkastella kriittisesti motivaation ja kouluarvosanan suhdetta kieltenopiskelussa ja pohtia tämän mahdollisia kielikoulutuspoliittisia implikaatioita. Tilastollisesti edustava tutkimusaineisto koostuu sähköisellä kyselyllä kerätyistä vastauksista ( $n=1$ 206), joista tässä tutkimuksessa tarkastelen perusopetuksen jälkeen lukiokoulutukseen tai ammatilliseen koulutukseen aikovien, kieliopinnoistaan arvosanansa ilmoittaneiden oppilaiden vastauksia $(n=981)$. Tutkimuksessa oppilaiden joukosta on aiemmissa analyyseissä löydetty (Kangasvieri, 2019) viisi motivaatioprofiilia: motivoitumattomimmat, keskivertomotivoituneet alhaisella kielijännityksellä, keskivertomotivoituneet, motivoituneimmat ja kielijännittäjät. Nyt näiden motivaatioprofiilien yhteyttä oppilaiden koulutusvalintaan selvitetään huomioimalla arvosanan vaikutus. Oppilaiden vastauksista tehtiin logistinen regressioanalyysi, jonka tuloksista käy ilmi, että todennäköisyys kussakin profiilissa mennä lukioon tai ammatilliseen koulutukseen riippuu arvosanasta. Logistinen regressiomalli selittää noin 30 prosenttia oppilaiden jatkosuunnitelmien valinnoista. Lisäksi tuloksista selviää, että mitä motivoituneempi oppilas on kieltenopiskelussaan, sitä korkeamman arvosanan hän kokee tarvitsevansa aikoakseen jatkaa perusopetuksen jälkeen lukioon. Vastaavasti heikommin motivoituneet oppilaat aikovat jatkaa lukioon huonommilla arvosanoilla kuin motivoituneemmat oppilaat. Koulutusvalinnassa on myös aina kyse oppilaiden koulutuksellisesta tasa-arvosta ja tasavertaisuudesta. Kaikilla on oltava lähtökohtaisesti samanlaiset ja tasavertaiset mahdollisuudet valita itselleen parhaimmaksi kokemansa vaihtoehto.
\end{abstract}

In this article I explore the relationship between Finnish ninth graders' L2 motivational profiles, language grades and future study plans after basic education. The aim of the study is to critically explore the relationship between motivation and language grades and reflect on the possible implications of this for language education policies. The statistically representative data was collected with an e-questionnaire $(n=1206)$. For this study, I analysed those who planned to continue their studies to general upper secondary school or vocational education after basic education, and who submitted their language grade ( $n=981)$. In earlier analyses of the study (Kangasvieri, 2019), five motivational profiles were found: the least motivated, averagely motivated with low anxiety, averagely motivated, the most motivated and students with high anxiety. In this study, the connection between these motivational profiles and students' education choice is explored, taking into account the effect of grades. A logistic regression analysis

Corresponding author's email: teija.kangasvieri@gmail.com

eISSN: 1457-9863

Publisher: University of Jyväskylä, Language Campus

(C) 2021: The authors

https://apples.journal.fi

https://doi.org/10.47862/apples.107414 
was conducted. The results show that the probability to continue to general upper secondary school or vocational education in each motivational profile depends on the grade. The model explains about 30 percent of the students' educational choices. Additionally, the results show that the more motivated the student is in his/her language studies, the higher grade he/she feels is needed in order to plan to continue to general upper secondary school after basic education. Correspondingly, less motivated students plan to continue to general upper secondary school with poorer grades than more motivated students. The educational choice is always a matter of students' educational equity and equality. In principle, everyone must have similar and equal opportunities to choose the best option for them.

Asiasanat: kielenoppimismotivaatio, motivaatioprofiili, arviointi, ammatillinen koulutus, lukio, koulutusvalinta

Keywords: L2 motivation, motivational profile, assessment, vocational education, general upper secondary school, educational choice

\section{Johdanto}

Oppimismotivaatiota on tutkittu runsaasti sekä kansainvälisesti että kansallisesti. Suomessa motivaatio on noussut keskiöön muun muassa PISA-tulosten myötä (Kupari ym. 2013; Välijärvi ym. 2015). Tulevaisuuden peruskoulua käsittelevässä raportissa (Harinen ym., 2015) motivaatio määritellään innostuneeksi ja innostavaksi sitoutumiseksi tavoitteelliseen toimintaan, ja sen merkitys keskeiseksi oppimistulosten kannalta. Motivaatiosta on tullut koulutuspoliittisesti kiinnostava aihe, mutta se siirtää huomiota yhteiskunnasta ja yhteisöstä yksilöön. Kotimaisessa tutkimuksessa nuorten toisen asteen koulutussiirtymää peruskoulusta toisen asteen koulutukseen on lähestytty erityisesti sisäisen ja ulkoisen motivaation (ks. esim. Vasalampi ym. 2010; Vasalampi \& Salmela-Aro, 2014) ja tavoiteorientaatioiden (ks. esim. Tuominen-Soini ym. 2012) kautta. Tässä tutkimuksessa tarkastelen koulutussiirtymää suhteessa motivaatioon opiskella vieraita kieliä.

Motivaation merkitys on kieltenopiskelussakin ilmeinen, mutta motivaatio on myös poliittinen käsite, kuten tässä Euroopan komission koulutuspoliittisesta dokumentista ilmenee:

Important though awareness raising among, and motivating the motivators may be, ultimately it is the learners who need to be motivated. Motivation is a key, if not the key, to successful language learning. Enhancing learner motivation is the crucial element in achieving the desired breakthrough in language learning across Europe (European Commission, 2007, p. 9).

Niin tärkeää kuin motivaattoreiden motivointi ja tietoisuuden lisääminen voi ollakin, loppujen lopuksi nimenomaan oppijoita pitää motivoida. Motivaatio on ratkaisu, ellei jopa tärkein ratkaisu menestyksekkääseen kieltenopiskeluun. Oppijoiden motivaation parantaminen on ratkaiseva tekijä halutun läpimurron saavuttamiseksi kieltenopiskelussa Euroopassa.

Vieraiden kielten opiskelu on vähentynyt suomalaisissa kouluissa jatkuvasti viime vuosina, ja vapaaehtoisia ja valinnaisia kieliä opiskelee yhä harvempi peruskoulun oppilas. Pelkästään englantia ja toista kotimaista kieltä opiskelevien 
osuus kasvaa (ks. Kangasvieri ym. 2011; Kumpulainen 2014; Pyykkö 2017; Tilastokeskus 2020, 2019b). Tutkimuksen lähtökohtana oli, että kielten valinnat tai valitsemattomuus heijastelevat oppilaiden motivaatiota opiskella vieraita kieliä. On toki mahdollista, että tilanne heijastelee myös yleisiä kieliasenteita ja kieli-ilmapiiriä tai on yksinkertaisesti vain seurausta kuntien synkistyneestä taloustilanteesta (ks. esim. Kyllönen \& Saarinen, 2010). Ensiksi mainitusta syystä tutkimuksessa selvitettiin perusopetuksen yhdeksäsluokkalaisten vieraan kielen oppimismotivaatiota ja erityisesti sitä, millaisia motivaatioprofiileja oppilaiden joukosta on löydettävissä (Kangasvieri, 2019). Helposti voisi olettaa, että kieltenopiskeluun motivoituneet ja niissä menestyvät, kielet arvokkaana pääomana näkevät oppilaat aikovat jatkaa lukioon, mutta onko tämä yhteys sittenkään näin suoraviivainen?

Artikkelissa raportoidut tulokset pohjautuvat laajaan peruskoulun yhdeksäsluokkalaisten parissa toteutettuun kyselytutkimukseen (Kangasvieri, 2019). Tässä artikkelissa tarkastelen aiemmin löydettyjen (Kangasvieri, 2019) motivaatioprofiilien yhteyttä oppilaiden kieliopinnoissaan saamiin arvosanoihin ja perusopetuksen jälkeisiin jatko-opiskelusuunnitelmiin. Alun taustoituksen jälkeen tarkastelen lähemmin tutkimuksen aikaisemmassa vaiheessa oppilaiden joukosta latentin profiilianalyysin avulla löydettyjä profiileja, oppilaiden arvosanoja ja jatkosuunnitelmia. Tämän jälkeen selvitän näiden yhteyksiä tarkastelemalla logistisen regressioanalyysin tuloksia, minkä jälkeen ennen kuin siirryn tuloksista tehtyihin johtopäätöksiin ja pohdintaan.

Kielenoppimismotivaation ja koulutusvalinnan yhteyttä ei ole maassamme aiemmin tutkittu ja siksi tämä tutkimus on erityisen tärkeä. Tutkimuksen tavoitteena on myös valottaa motivaation ja kouluarvosanan suhdetta kieltenopiskelussa, mikä tekee tästä tutkimuksesta myös kielikoulutuspoliittisesti kiinnostavan. Kieltenopiskelu on maassamme aina ollut luonteeltaan myös poliittinen aihe, kun ajatellaan esimerkiksi toisen kotimaisen kielen opiskelua kouluissa, globaalin englannin ylivaltaa yhteiskunnassamme tai suunnitelmia siitä, mitä kieliä olisi syytä opiskella ja kuinka paljon (ks. esim. Geber, 2010; Leppänen ym., 2009; Piri, 2001). Lisäksi kyse on myös koulutuksellisesta tasavertaisuudesta, sillä voisi helposti olettaa, että perinteisesti kielipainotteisemmaksi mielletty lukiokoulutus edellyttää voimakkaampaa kielenoppimismotivaatiota, yleistä opiskelumotivaatiota ja parempia arvosanoja kuin ammatilliseen koulutukseen hakeutuminen. Kielen roolia suhteessa koulutuksen osallisuuteen ja tasavertaisuuteen on tutkittu kansainvälisesti paljonkin (ks. esim. Tollefson \& Tsui, 2014), mutta Suomessa juuri tällaista tutkimusta ei ole aiemmin tehty.

Arviointi on ollut hyvin paljon esillä viime vuosina ja se on erittäin keskeinen uusissa Perusopetuksen opetussuunnitelman perusteissa (Opetushallitus [OPH], 2014). Opetushallitus onkin jo täydentänyt opetussuunnitelman arviointia käsittelevää lukua 6 Oppilaan oppimisen ja osaamisen arviointi. Täsmennykset tulivat kouluissa käyttöön 1.8.2020 ja niillä haluttiin vähentää arvioinnin sattumanvaraisuutta ja kuormittavuutta sekä parantaa oppilaiden yhdenvertaisuutta heidän hakeutuessaan toisen asteen opintoihin (OPH, 2020a, 2020b).

Suomalaisessa nyky-yhteiskunnassa myös toisen asteen koulutuksen panokset ovat selkeästi kasvaneet. Yhteiskunnastamme on tullut hyvin suorituskeskeinen, joten nuorilla on paine menestyä jo toisen asteen opinnoissaan, ja he vaativat itseltään aiempia sukupolvia enemmän (ks. esim. Suomen Kuvalehti [SKL], 2021a, 2021b). Tämä koskee erityisesti lukiokoulutusta, joka useimmiten toimii ponnahduslautana korkeakouluopintoihin (ks. lisää koulutussiirtymistä ja koulutukseen 
valikoitumisesta esim. Kalalahti ym., 2019; Mattila, 2020; Tuononen \&Vanhalakka-Ruoho, 2016). Vasalampi ja Salmela-Aro (2014) havaitsivat tutkimuksessaan, että omat koulutukselliset tavoitteensa kuormittaviksi kokeneet oppilaat päätyivät todennäköisemmin lukioon kuin ammatilliseen koulutukseen. Lisäksi Salmela-Aro ym. (2008) toteavat, että varsinkin tytöt kokevat lisääntyvästi riittämättömyyden tunteita lukiossa. Lukiokoulutukseen hakeutuminenhan saattaa edellyttää peruskoululaisilta jo lähtökohtaisesti arvosanoin mitattuna parempaa koulumenestystä kuin ammatilliseen koulutukseen hakeutuminen.

Lisäksi kun kielet aiemmin nähtiin sivistyspääomana, joita tuli osata niiden itsensä ja puhtaasti monipuolisen kielitaidon takia, nyt kielet ovat myös statussymboli tai niitä opiskellaan niiden markkina-arvon takia (ks. lisää esim. Kosunen, 2016; Beacco, 2007). Kieli vaikuttaa kytkeytyvän perheen sosioekonomiseen asemaan siten, että kielivalintoja käytetään kouluvalinnan yhtenä perusteena, eli kielivalinnalla varmistetaan haluttu koulu lapselle. Tässä artikkelissa on siis tarkoitus tutkia, millainen osa koulutusvalikoitumista kieltenopiskelu on. Onko kieltenopiskelulla roolia koulutusvalinnassa ja sitä kautta koulutuksen tasavertaisuudessa?

\subsection{Vieraan kielen oppimismotivaatiosta ja sen tutkimuksesta}

Kielenoppimismotivaation tutkimus on vuosien saatossa saanut paljon vaikutteita yleisestä psykologiasta ja yleisen oppimismotivaation tutkimuksesta, mutta se on kuitenkin oma erillinen tutkimusalansa, joka huomioi kielenoppimisen erityispiirteet (Dörnyei \& Ushioda, 2011). Tutkimus sai alkunsa Kanadassa, ja 1980luvun lopulle asti motivaatiota tutkittiin sosiaalipsykologisessa viitekehyksessä (esim. Gardner, 1985). Sen jälkeen 1990-luvulla mukaan tuli koulutuspsykologian näkökulma, jossa tutkimus siirtyi luokkahuoneeseen (esim. Julkunen, 1989), ja alettiin myös selvittää motivaatiota prosessina sekä sen vaihtelua (esim. Dörnyei \& Ottó, 1998). 2000-luvulla kielenoppimismotivaatiota on lähestytty useista uusista näkökulmista: motivaatiota on tutkittu suhteessa identiteettiin, minäkuvaan, oppijan autonomiaan ja toimijuuteen (esim. Dörnyei \& Ushioda, 2009, 2011; Murray ym. 2011), ja uusimmissa teorioissa motivaatiota on lähestytty dynaamisena systeeminä (esim. Dörnyei ym. 2015) ja suunnattuina tai ohjattuina motivaatiovirtauksina (esim. Dörnyei ym. 2016; Al-Hoorie \& Macintyre, 2020; Lamb ym., 2019).

Tutkimuksissa on osoitettu kielijännityksen (language anxiety) vaikuttavan oppijan motivaatioon ja siten erilaisten affektiivisten tekijöiden välityksellä oppimissaavutuksiin. Kielijännityksen motivaation kautta kulkeva vaikutus on erityisen vahva. Yhdessä muiden affektiivisen alueen tekijöiden, kuten esimerkiksi asenteiden, motivaation ja minäkäsityksen kanssa kielijännitys muokkaa oppilaan kielenoppimiskokemuksia (Pihko, 2009.)

Vieraiden kielten opiskeluun ja oppimiseen liittyvästä motivaatiosta on tehty paljon kansainvälistä tutkimusta, jossa motivaatiota on tarkasteltu erilaisista lähtökohdista ja näkökulmista (ks. lisää esim. Boo ym. 2015; Dörnyei \& Ushioda, 2011). Suomessa vieraan kielen oppimismotivaatiota tutkittiin erityisesti 1990-luvulla (esim. Julkunen, 1998a, 1998b; Julkunen \& Borzova, 1997; Nikki, 1992). Meillä on myös tehty tutkimusta erityisesti ruotsin kielen oppimismotivaatiosta (Kovanen, 2004; Kantelinen \& Kettunen, 2004; Juurakko-Paavola \& Palviainen, 2011). Lisäksi on tutkittu suomen kielen oppimismotivaatiota venäjää kotikielenään puhuvilla peruskoululaisilla (Ullakonoja ym. 2013) sekä saksan kielen oppimismotivaatiota yliopistoopiskelijoiden parissa (Hurskainen \& Ylönen, 2015). Nämä tutkimukset ovat kuitenkin olleet huomattavasti suppeampia, kuin tämän artikkelin laaja-alainen tutkimus. 
Lähes vuosikymmen sitten toteutetussa Opetushallituksen vieraiden kielten oppimistulosten arvioinnissa selvitettiin peruskoulun päättävien (n=10 751) käsityksiä kielten hyödyllisyydestä, kielistä pitämisestä ja omasta osaamisesta, jotka ovat kaikki läheisesti kytköksissä kielenoppimismotivaatioon. Arvioinnissa ei kuitenkaan tämän yksityiskohtaisemmin selvitetty oppilaiden motivaation rakennetta (Kansallinen koulutuksen arviointikeskus [KARVI], 2013). Arvioinnin tuloksista selviää, että A-oppimäärissä oppilaiden myönteisimmät käsitykset liittyivät oppiaineen hyödyllisyyteen. Erityisesti englanti, venäjä ja saksa koettiin hyödylliseksi niin työelämässä, jatko-opinnoissa kuin arkipäivän viestintätilanteissakin. Oppiaineesta pitäminen oli puolestaan keskimäärin neutraalia kaikissa arvioiduissa kielissä. Omaan osaamiseensa oppilaat luottivat eniten englannissa, hiukan vähemmän ruotsissa ja vähiten ranskassa. B-oppimäärissä puolestaan oppilaiden käsitykset olivat keskimäärin neutraaleja niin oppiaineesta pitämisen, hyödyllisyyden kuin oman osaamisenkin suhteen. Ainoastaan B-venäjässä oppilaiden käsitykset venäjän hyödyllisyydestä olivat keskimäärin myönteiset. (Hildén \& Rautopuro, 2014a, 2014b, 2014c; Härmälä \& Huhtanen, 2014; Härmälä ym. 2014). Tässä artikkelissa raportoidun tutkimuksen tavoitteena onkin ollut selvittää suomenkielisten peruskoulun yhdeksäsluokkalaisten vieraan kielen oppimismotivaatiota mahdollisimman laaja-alaisesti, sillä vastaavaa yhtä suurella otoksella toteutettua motivaatiotutkimusta ei ole Suomessa ennen tehty. Edellä mainitun vieraiden kielten oppimistulosten arvioinnin (Härmälä ym. 2014) englannin kieltä koskevan aineiston pohjalta tehdyssä jatkotutkimuksessa selvitettiin, miten edellä mainitut käsitykset olivat yhteydessä oppilaan jatko-opintosuunnitelmiin. Tuloksista selvisi, että käsitykset olivat myönteisempiä lukioon aikovilla (Härmälä ym., 2017).

\subsection{Kieltenopiskelusta ja osaamisen arvioinnista suomalaisessa perusopetuksessa}

Perusopetuksessa opiskellaan kaikille yhteisenä pakollista A1-kieltä, joka alkoi pitkään useimmiten alakoulun 3. vuosiluokalla. Tähän on syksyllä 2018 tullut ja vuonna 2020 voimaan astunut muutos siten, että ensimmäisen vieraan kielen eli A1-kielen opiskelu alkaa nykyään jo viimeistään peruskoulun ensimmäisen vuoden keväällä (Opetus- ja kulttuuriministeriö [OKM], 2018; OPH, 2019a). Vapaaehtoisen A2-kielen voi aloittaa joko 4. tai 5. vuosiluokalla, tosin nykyään jotkut aloittavat sen jo 3. vuosiluokalla. Pakollinen toinen kotimainen kieli eli B1-kieli alkaa nykyään 6. vuosiluokalla aiemman 7 . vuosiluokan sijaan. Yläkoulun valinnaisen B2-kielen opiskelu alkaa vuosiluokalla 7-9, useimmiten 8. vuosiluokalla. (Kumpulainen, 2014; OPH, 2019a). Opetushallituksen tilastot perusopetuksen kielivalinnoista vuodelta 2019 osoittavat, että vuonna 2017 englantia opiskeli pakollisena A1-kielenä 89,9 prosenttia oppilaista. Alakoulun vapaaehtoista A2-kieltä opiskeli puolestaan 27 prosenttia oppilaista. Yläkoulun valinnaisen kielen oli valinnut noin 17 prosenttia oppilaista (OPH, 2019a.) Valinnaisia kieliä opiskelevien oppilaiden määrä on pudonnut huomattavasti 1990-luvun puolivälin määristä, jolloin A2-kielen opiskelijoita oli enimmillään 41 prosenttia ja B2-kielen vastaavasti 43 prosenttia (OPH, 2019a). Kieltenopiskelussa on maassamme huomattavia alueellisia eroja siten, että suurissa kaupungeissa ja Etelä-Suomessa opiskellaan kieliä enemmän (ks. esim. KARVI, 2013), ja tytöt opiskelevat kieliä edelleen huomattavasti enemmän kuin pojat (OPH, 2019a).

Kieltenopetuksen varhentaminen eli ensimmäisen vieraan kielen opiskelun aloittaminen jo esiopetuksessa tai perusopetuksen 1. vuosiluokalta alkaen oli puolestaan yksi Sipilän hallituksen osaamisen ja koulutuksen kärkihankkeista. Hankkeen 
tavoitteena oli motivoida oppilaita, tukea heidän kieltenoppimistaan ja monipuolistaa kielivalintoja. Hankkeen seurauksena syntyi myös Riitta Pyykön selvitys Monikielisyys vahvuudeksi. Selvitys Suomen kielivarannon tilasta ja tasosta (2017).

Uusimmissa perusopetuksen opetussuunnitelman perusteissa (OPH, 2014) on annettu hyvin yksityiskohtaiset tavoitteet vieraiden kielten eri oppimäärille. Kielenoppimista arvioidaan monipuolisesti, myös itse- ja vertaisarvioinnein. Arvioinnissa huomioidaan kaikki kielitaidon osa-alueet, joita arvioidaan Eurooppalaisen viitekehyksen pohjalta laaditun suomalaisen sovelluksen avulla (Hildén \& Takala, 2007). Opetussuunnitelmassa on tarkat valtakunnalliset päättöarvioinnin kriteerit hyvälle osaamiselle eli arvosanalle 8 , joita on äskettäin täsmennetty. Opetushallitus on myös laatinut uudet päättöarvioinnin kriteerit kaikkiin oppiaineisiin myös arvosanoille 5, 7 ja 9. Uudet kriteerit otettiin käyttöön syksyllä 2021 $(\mathrm{OPH}, 2020 \mathrm{c})$. Uuden opetussuunnitelman mukaan opetuksen järjestäjä voi päättää, onko arviointi vuosiluokilla 1-7 sanallista tai numeroarviointia tai niiden yhdistelmä, kun taas vuosiluokilla 8-9 käytetään numeroarviointia asteikolla 4-10 ( 4 = hylätty suoritus, 10 = erinomainen; päättöarvioinnissa 5 välttävä - 10 erinomainen). (OPH 2014.)

Viimeisimmän perusopetuksen opetussuunnitelmauudistuksen yhteydessä keskusteltiin paljon arvioinnin merkityksestä oppimisessa. Tutkimusten mukaan arvioinnilla voi olla myönteisen vaikutuksen lisäksi myös kielteinen vaikutus motivaatioon, ja erityisesti niin sanotut high stakes -testit ${ }^{1}$ voivat vähentää opiskelijoiden motivaatiota (ks. esim. Ushioda 2013). Arvioinnin vaikutus motivaatioon liittyy vahvasti siihen, millaisena oppija näkee itsensä arvioinnin seurauksena. (Harlen, 2012; Harlen \& Crick, 2003.) Tämä tiedostetaan myös Perusopetuksen opetussuunnitelman perusteissa $(\mathrm{OPH}, 2014)$, ja siitä syystä onkin ehkä hyvä, että niissä numeroin tapahtuvaa arviointia siirrettiin useita vuosiluokkia ylöspäin, ja sanallista arviointia annetaan huomattavasti pidempään kuin aikaisemmin. Sittemmin Opetushallitus on tarkentanut perusopetuksen päättöarvioinnin kriteereitä $(\mathrm{OPH}, 2020 \mathrm{c})$, kuten edellä mainittiin. Uusilla kriteereillä tavoitellaan sitä, että oppilaiden arvosanat olisivat keskenään entistä vertailukelpoisempia esimerkiksi silloin, kun oppilaat hakevat toisen asteen opintoihin. Sisältötavoitteiden sijasta tärkeämpää on myös kuvata oppilaan osaaminen eri arvosanoilla.

\subsection{Peruskoulun päättäneiden hakeutuminen toisen asteen opintoihin}

Tilastokeskuksen (2019) mukaan noin 53,4 prosenttia kaikista 9. luokan päättäneistä oppilaista haki lukioon ja vastaavasti 41,3 prosenttia ammatilliseen koulutukseen vuonna 2018. Prosenttiosuudet ovat hieman muuttuneet viimeisten 15 vuoden aikana, sillä esimerkiksi vuonna 2002 vastaavat prosentit olivat 58,2 ja 39,2. Lukiokoulutukseen hakeutuu siis yleensä yli puolet perusopetuksen päättävistä nuorista. Sukupuolten välillä on eroa koulutukseen hakeutumisessa siten, että esimerkiksi vuonna 2018 tytöistä 66,3 prosenttia haki lukioon ja 33,7 prosenttia ammatilliseen koulutukseen, vastaavien prosenttien pojilla ollessa 44,5 ja 55,5. (Tilastokeskus 2019a.)

Metropolialueen nuorten $(n \approx 10000)$ toisen asteen koulutusvalintaa selvittäneessä raportissa (Hotulainen ym., 2016) todetaan, että perusopetuksen päättöarvosanoilla on suuri merkitys siinä, hakeeko nuori lukioon vai ammatilliseen koulutukseen. Metropolialueen nuorten toisen asteen valinta oli myös vahvasti sukupuolittunutta siten, että tytöt hakevat lukioon ja pojat ammatilliseen koulutukseen, mikä johtui siitä, että tyttöjen arvosanat ovat poikia parempia. Myös kuntien 
väliset sosioekonomiset erot ja vanhempien koulutustaso vaikuttivat vahvasti nuorten koulutusvalintoihin. Metropolialueen 13500 nuoresta kaksi kolmesta haki ensisijaisesti lukioon keväällä 2014 (Kupiainen, 2016a). Raportissa todetaan myös, että nuorten toiselle asteelle etenemisen taustalla olevaan koulumenestykseen vaikuttaa lisäksi erittäin merkittävästi myös motivaatio (Kupiainen, 2016b). Motivaatiosta luotiin hetkessä merkittävä koulutuspoliittinen tekijä ja sitä tarjottiin lääkkeeksi parempaan koulumenestykseen ja yhä parempiin PISA-tuloksiin (ks. esim. OKM, 2015, Rautopuro \& Juuti, 2018; YLE, 2014).

Koko maan nuorten koulutusvalintoja selvittäneen raportin (Lahtinen, 2019) mukaan nuorten koulutusvalinnat kumpuavat heidän yksilöllisten elämäntilanteidensa kokonaisuuksista, joissa merkityksellisiä ovat niin perhe, kaverit, harrastukset, sosiaaliset ja kulttuuriset ilmiöt, rakenteet ja käytännöt kuin alueelliset tekijät. Nuoret hahmottavat siis lähtökohtaisesti valintatilanteitaan kovin eri tavoin riippuen aiemmasta opintomenestyksestään ja nykyhetken kiinnostuksenkohteistaan. He puntaroivat koulutusvalintojaan toisen asteen koulutukseen pääasiallisesti omien motivaatioidensa ja epävarmuuksiensa pohjalta. Koulutusvalintojen kehykset liittyvät ennen kaikkea siihen, onko nuori suuntautumassa toiselle asteelle lukiokoulutukseen vai ammatilliseen koulutukseen ja millä perusteilla hän tätä pohdiskelee.

Vasalampi ja Salmela-Aro (2014) toteavat, että useissa Euroopan maissa siirtymä peruskoulusta toisen asteen koulutukseen on yksi merkityksellisimmistä koulutuksellisista siirtymistä nuorten elämässä. Onkin tärkeää, että nuori tekee koulutusvalinnan itse omien kiinnostuksen kohteidensa ja arvojensa pohjalta, sillä tämä edesauttaa häntä motivoitumaan sisäisesti koulutuksellisiin tavoitteisiinsa. Tätä taustaa vasten onkin mielenkiintoista tarkastella, millainen yhteys erityisesti kielenoppimismotivaatioprofiileilla on toisen asteen koulutusvalintoihin: suuntautuvatko kieliopintoihin motivoituneet lukioon ja heikommin motivoituneet ammatilliseen koulutukseen? Entä miten tähän yhteyteen vaikuttaa kieliopinnoista saatu arvosana? Lukiokoulutukseen on perinteisesti sisältynyt huomattavasti enemmän kieliopintoja, kuin ammatillisen peruskoulutuksen tutkintoihin (ks. OPH, 2017, 2019b), mutta vaikuttaako tämä siihen, millainen koulutusvalinta erilaisissa vieraiden kielten motivaatioprofiileissa tehdään? En oleta, että vieraat kielet vaikuttavat ratkaisevasti peruskoulun jälkeisiin jatkosuunnitelmiin, vaan nimenomaan tutkimuksessani selvitän, ovatko vieraiden kielten opiskeluun liittyvät motivaatiotekijät yhteyksissä peruskoulun jälkeisiin valintoihin. Aiemman tutkimuksen perusteella tiedetään jo, että kielivalinnoissa on alueellisia ja sosioekonomisia eroja (ks. erityisesti OPH, 2019a; KARVI, 2013; Kangasvieri ym. 2011), joten peruskoulun jälkeiset valinnat heijastelevat näitä eroja. Esimerkiksi korkean sosioekonomisen statuksen asuinalueella asuva oppilas opiskelee A-kielenä keskimääräistä useammin muuta kuin englantia. A2-kieltä opiskellaan vain puolessa Suomen kunnista. Kansallisen koulutuksen arviointikeskuksen, Karvin (2020) arviointitulosten mukaan perusopetuksessa jatko-opintoihin ja uravalintoihin ohjauksen saatavuus ja saavutettavuus ovat pääosin hyvällä tasolla. Lisäksi oppivelvollisuus laajenee toiselle asteelle ja muuttuu maksuttomaksi elokuusta 2021 alkaen, mikä myöskin vaikuttanee nuorten koulutusvalintoihin ja -siirtymiin (OKM, 2020a, 2020b).

Tutkimukseni tavoitteena on löytää vastauksia siihen, millä tavalla kieliopinnot (motivaatio ja kielten arvosana) vaikuttavat oppilaiden koulutusvalintaan ja siten koko koulutuspolkuun. 
Tutkimuskysymykset ovat:

1) Missä määrin vieraan kielen oppimismotivaatioprofiileilla on yhteyttä oppilaiden jatko-opintosuunnitelmiin?

2) Mitä yhteyksiä kielestä saadulla arvosanalla on oppilaan jatko-opintosuunnitelmiin?

3) Onko kieltenopiskelulla rooli koulutusvalinnassa ja sitä kautta koulutuksen tasavertaisuudessa?

\section{Tutkimuksen aineisto ja metodit}

Tutkimuksen tilastollisesti edustava aineisto kerättiin sähköisellä kyselyllä käyttäen harkittua monivaiheista ryväsotantaa. Aineisto kerättiin aikavälillä elokuu 2012 - tammikuu 2013. Kysely kattoi yhteensä 13 kielenoppimismotivaation ulottuvuutta, joita kartoitettiin väittämillä, joihin oppilaat vastasivat Likertin asteikolla 5 Pitää täysin paikkansa - 1 Ei pidä ollenkaan paikkaansa. Kysely perustui pääosin kotimaiseen ja kansainväliseen tutkimukseen (Gardner, 1985, 2004; Dörnyei, 1990, 2001; Julkunen, 1998a, 1998b; Julkunen \& Borzova, 1997), ja sen tavoitteena oli kartoittaa suomalaisoppilaiden motivaatiota kokonaisvaltaisesti tekemällä synteesiä aiemmissa tutkimuksissa löydetyistä motivaatioulottuvuuksista.

Tässä tutkimuksessa motivaation ulottuvuuksista 10 jaoteltiin kielitasolle, oppijan tasolle ja oppimistilanteen tasolle Dörnyein (1994) teorian mukaisesti. Kielitasolla selvitettiin instrumentaalista, integratiivista, kognitiivista ja kommunikatiivista ulottuvuutta; oppijan tasolla motivaation intensiteettiä, kieliminää, ideaalia kieliminää ja kielijännitystä; oppimistilanteen tasolla opettajaan ja oppituntiin liittyviä motivaatiokomponentteja. Lisäksi kyselyyn sisällytettiin oppilaiden läheisten (significant others) ulottuvuus, joka sisälsi vanhempien rohkaisun ja ystävien vaikutuksen, sekä yhteiskunnan odotuksia kartoittaneen ulottuvuuden. (Kangasvieri, 2019).

Lisäksi kyselyssä oli joukko taustakysymyksiä, joilla selvitettiin oppilaiden kielivalintojen ja valitsematta jättämisen syitä sekä kielten käyttöä ja kiinnostusta kielten opiskeluun (ks. Kangasvieri, hyväksytty julkaistavaksi). Tutkimuksen kohde olivat perusopetuksen yhdeksäsluokkalaiset. Heidät valittiin tutkimuskohteeksi siitä syystä, että tuossa vaiheessa koulupolkua kaikki kielivalinnat ovat oppilailla tehtyinä. Kysely toteutettiin kouluissa tietokoneluokassa ja yhden kielen oppitunnin aikana. Kyselyn vastaukset analysoitiin tilastollisin menetelmin. Tarvittavat tutkimusluvat hankittiin aineistonkeruun edetessä kunkin kunnan ja koulun vaatimalla tavalla. Lisäksi tutkimus rajattiin koskemaan vain suomenkielistä perusopetusta, sillä ruotsinkielisessä perusopetuksessa kieliohjelma toteutuu hieman eri tavalla.

Tutkimus kohdistui sekä pakollisiin että vapaaehtoisiin ja valinnaisiin kieliin. Pakolliseksi kieleksi valikoitui englanti, sillä se on yleisin yhteisenä aloitettava kieli suomenkielisessä perusopetuksessa. Vapaaehtoisia A2-kieliä olivat saksa, ranska ja venäjä. B2-kielinä mukana olivat saksa, ranska, venäjä ja espanja. Toinen kotimainen kieli ruotsi jätettiin tutkimuksen ulkopuolelle. Vaikka ruotsin kieli on oppilaalle useimmiten vieras kieli, kieliohjelman näkökulmasta se ei ole vieras, vaan toinen kotimainen kieli. Vastaajissa ty töt olivat en emmistönä kaikissa oppimäärissä ja heidän osuutensa vastaajista lisääntyi kieliohjelman edetessä siten, että A1-kielessä tyttöjä oli 54 prosenttia, A2-kielessä 61 prosenttia ja B2-kielessä jo 70 prosenttia. Kaikkiaan kyselyyn osallistui oppilaita yhteensä 33 koulusta. Vastauksia kertyi yhteensä 1206 (ks. taulukko 1). Vastaajista 59,7 \% oli tyttöjä ja vastaavasti 40,3 \% poikia. Useamman eri kielen näkökulmasta vastanneita oppilaita on aineistossa 136. 
Taulukko 1. Vastaukset oppimäärittäin ja kielittäin.

\begin{tabular}{lllll}
\hline Kieli & A1 & A2 & B2 & Yhteensä \\
\hline englanti & 709 & & & 709 \\
\hline saksa & & 113 & 145 & 258 \\
\hline ranska & 49 & 107 & 156 \\
\hline venäjä & 10 & 30 & 40 \\
\hline espanja & & & 43 & 43 \\
\hline Yhteensä & 709 & 172 & 325 & 1206 \\
\hline
\end{tabular}

Aineistolle tehtiin latentti profiilianalyysi tilasto-ohjelmistolla Mplus versiolla 5.1. motivaatioprofiilien löytämiseksi (ks. Kangasvieri, 2019) sekä regressioanalyysi tilasto-ohjelmistolla IBM Statistics SPSS 24 aineistosta löytyneiden profiilien, arvosanojen ja jatkosuunnitelmien välisten yhteyksien selvittämiseksi.

\subsection{Oppilaiden motivaatioprofiilit}

Aineistolle aiemmin tehty latentti profiilianalyysi tuotti yhteensä viisi toisistaan erottuvaa motivaatioprofiilia (ks. Kangasvieri, 2019). Kaksi viidesosaa oppilaasta (39 \%) kuului motivoituneimpien oppilaiden ryhmään. Vajaa kolmannes (29\%) oppilasta oli keskivertomotivoituneita, joiden kielijännitys oli matalalla tasolla. Vajaa viidennes (18 \%) puolestaan oli keskivertomotivoituneita. Motivoitumattomimpien profiiliin kuului kahdeksan prosenttia oppilaista ja kielijännittäjiin kuusi prosenttia yläkouluikäisistä kielenoppijoista. Motivaatioprofiileissa oli siis lähinnä kyse eroista motivaation voimakkuudessa.

Tilastollisten analyysien tulokset osoittivat, että oppilaat ovat motivoituneempia opiskelemaan englantia, kuin valinnaisia kieliä. Valinnaisista kielistä tämä koski erityisesti saksaa. Lisäksi oppilaat ovat motivoituneempia opiskelemaan valinnaisia B2-kieliä kuin vapaaehtoisia A2-kieliä. Englannin opiskelijat ovat yliedustettuna motivoituneimpien ryhmässä ja valinnaisten kielten opiskelijat ovat yliedustettuna motivoitumattomimpien ryhmässä.

Oppilailla oli kyselyssä mahdollisuus antaa vapaita kommentteja esimerkiksi kyselystä tai kieltenopiskelusta. Noin neljännes oppilaista $(n=299)$ oli jättänyt kommentin avoimeen kenttään. Eniten he kommentoivat kyselyä, mutta moni kirjoitti mielipiteitä muun muassa eri kielistä, omasta kieltenopiskelusta ja kieltenopettajasta. Kun näitä vastauksia verrattiin oppilaan motivaatioprofiiliin, kävi ilmi, että oppilaiden kirjoittamista kommenteista löytyi kuvauksia, jotka sopivat hyvin siihen profiiliin, johon he sijoittuivat.

Oppilaiden kuvauksista (suorat lainaukset oppilaiden vastauksista) voi tulkita, että motivoitumattomimmilla oppilailla (profiili 1) on opiskeluunsa välinpitämätön ja jollain tapaa luovuttanut asenne, eikä mielenkiintoa kielen opiskeluun enää ole olemassa lainkaan.

(1) Olen menettänyt mielenkiintoni kyseiseen kieleen pysyvästi. (motivoitumattomimmat) (poika B2-saksa)

Keskivertomotivoituneet alhaisella kielijännityksellä (profiili 2) ovat puolestaan oppilaita, jotka tekevät kyllä töitä opintojen eteen, mutta eivät toisaalta ole sen syvemmin kiinnostuneita opiskelemastaan kielestä. Heitä voisikin kuvailla ikään kuin suorittajiksi. Voisi ehkä jopa ajatella, että nämä ovat oppilaita, joiden puolesta huoltaja on saattanut valita opiskeltavan kielen. 
(2) Voin opiskella sitä ja pitää arvosanat hyvinä, mutta en koskaan tule pitämään kielestä. (keskivertomotivoituneet alhaisella kielijännityksellä) (tyttö, B2-saksa)

"Keskivertomotivoituneiden (profiili 3) ryhmässä motivaatio tuntuu vaihtelevan ajan ja tilanteen mukaan. Heitä oppimisen ilo yhä motivoi jatkamaan kielen opiskelua ajoittaisesta epäröinnistä huolimatta.

(3) välillä ottaa päähän kun valitsi yhden opiskeltavan kielen lisää mutta ei kyllä silloin kun oppii jotain uutta(: (keskivertomotivoituneet) (tyttö, B2-ranska)

Motivoituneimmat (profiili 4) asennoituvat kieltenopiskeluun tavoitteellisesti ja he ajattelevat ehkä muita profiileja selkeämmin opiskelusta koituvaa hyötyä. Heille kielet ja kielitaito ovat ikään kuin pääomaa.

(4) Kielten opiskelu on mielestäni tärkeää ja haluaisin oppia paljon kieliä. (motivoituneimmat) (tyttö, B2-saksa)

Kielijännittäjien profiiliin (profiili 5) sijoittuvat ne oppilaat, joiden kieltenopiskelua dominoi kokemus itsestä huonona kielenoppijana ja epäonnistumisen pelko vie heiltä oppimisen iloa. Näiden oppilaiden kokemus kieltenopetuksesta luokkahuoneessa luokkakavereiden, ja opettajan kanssa on erittäin kielteinen ja ahdistava.

(5) [...] minua ihan pelottaa mennä tunneille koska olen huono ääntämään ja minulle nauretaan. (kielijännittäjät) (poika, B2-ranska)

Oppilaat jakautuvat siis selkeästi toisistaan erottuviin kielenoppimismotivaatioprofiileihin. Seuraavaksi tarkastelen, millaisia jatkosuunnitelmia näihin eri profiileihin sijoittuvilla oppilailla on perusopetuksen jälkeen.

\subsection{Oppilaiden kielten arvosanat}

Kuten edellä mainittiin, suomalaisessa perusopetuksessa oppilaiden arvioinnissa on käytössä arvosanat 4-10 (4 = hylätty suoritus, 10 = erinomainen) $(\mathrm{OPH}, 2014)$. Kyselyyn vastaajia pyydettiin ilmoittamaan edellisessä todistuksessaan kyseisessä kielessä saamansa arvosana. Käytännössä tämä tarkoitti oppilaiden joko 8 . luokan kevätlukukauden tai 9. luokan syyslukukauden päätteeksi saamaa arvosanaa. Arvosanatieto siis perustui oppilaiden omaan ilmoitukseen, eikä niitä voitu tarkistaa esimerkiksi opettajilta tai muulta koulun hallintohenkilökunnalta.

Tarkasteltaessa arvosanoja motivaatioprofiileittain oli huomattavissa, että profiilien 1 (motivoitumattomimmat) ja 3 (keskivertomotivoituneet) jakaumat olivat suurin piirtein normaalisti jakautuneita, mutta profiileissa 2 (keskivertomotivoituneet alhaisella kielijännityksellä) ja 5 (motivoituneimmat) jakaumat olivat oikealle (hyviin arvosanoihin) vinoja, eli mitä motivoituneempi oppilas, sitä parempi arvosana.

\subsection{Oppilaiden jatkosuunnitelmat perusopetuksen jälkeen}

Kyselyssä oppilailta kysyttiin, mitkä ovat heidän jatkosuunnitelmansa perusopetuksen jälkeen. Vastausvaihtoehtoja oli seitsemän ja ne jakautuivat seuraavasti:

Vastaajista selkeä enemmistö oli menossa lukioon $(60,7 \%)$ ja vain noin reilu viidennes $(22,4 \%)$ ammatilliseen koulutukseen. Vastaajista kaksoistutkinnon ai- 
koi suorittaa 6,7 \%, töihin 0,4 \% ja kymppiluokalle 0,4 \%, muualle 2,4 \% ja epätietoisia oli $7,0 \%$. Näin ollen aineiston jakauma on lievästi vino lukioon aikovien suuntaan (vrt. kaikkien yhdeksäsluokkalaisten jakauma ylempänä tässä artikkelissa), eli aineistossa on enemmän lukioon aikovia, kuin yhdeksäsluokkalaisissa koko maassa (Tilastokeskus 2019a).

Kaikki vapaaehtoista tai valinnaista kieltä opiskelevat oppilaat eivät toki aikoneet jatkaa lukiokoulutukseen. Vaikka enemmistö ylimääräisen kielen opiskelijoista oli aikeissa jatkaa joko lukiokoulutukseen tai ammatilliseen koulutukseen, jäi heitä myös muihin jatkosuunnitelmavaihtoehtoihin (ks. taulukko 2). Täten ei voi tehdä johtopäätöstä, että ylimääräinen kieli automaattisesti tarkoittaa lukiokoulutusta.

Koko maan opiskelijoiden haut ja tämän tutkimuksen oppilaiden hakuaikeet jatko-opintoihin eivät kuitenkaan poikkea toisistaan täysin ja toki hakuprosenteissa on pientä vaihtelua muutenkin vuosittain. Ero prosenttiosuuksissa selittynee silläkin, että tutkimushetkellä kyse oli vasta oppilaan aikomuksesta. Nämä on toki hyvä tiedostaa tutkimuksen tulosten yleistettävyyteen mahdollisesti vaikuttavana tekijänä.

Taulukko 2. Vapaaehtoisten ja valinnaisten kielten opiskelijoiden määrät lukiokoulutukseen ja ammatilliseen koulutukseen aikovissa.

\begin{tabular}{lcc}
\hline & $\begin{array}{c}\text { AION } \\
\text { LUKIOKOULUTUKSEEN }\end{array}$ & $\begin{array}{c}\text { AION AMMATILLISEEN } \\
\text { KOULUTUKSEEN }\end{array}$ \\
\hline kaikki & 732 & 270 \\
\hline A2-kieltä opiskelevat & 134 & 14 \\
\hline B2-kieltä opiskelevat & 248 & 35 \\
\hline
\end{tabular}

Analyysiin otettiin kuitenkin mukaan vain lukioon tai ammatilliseen koulutukseen aikovat, arvosanansa kyselyssä ilmoittaneet opiskelijat $(n=981)$, sillä muiden vaihtoehtojen oppilasmäärät jäivät jokseenkin vähäisiksi. Toisen asteen koulutuksen ulkopuolelle (kymppiluokka, töihin, muualle ja "en tiedä vielä") jäi aineistossa $10 \%$ oppilaista. Heistä $52 \%$ oli tyttöjä ja $48 \%$ poikia.

\section{Logistinen regressioanalyysi}

Logistista regressioanalyysiä (logistic regression) voidaan käyttää tilanteissa, joissa selitettävä muuttuja on kaksiluokkainen eikä jatkuva, kuten lineaarisessa regressioanalyysissä. Logistisessa regressioanalyysissä selittävä muuttuja voi olla kaksi- tai useampiluokkainen tai jatkuva. (Eddington, 2015; Gellman \& Hill, 2007; Peng ym. 2002.) Näin ollen logistinen regressioanalyysi soveltuu motivaatioprofiilien, jatkoopintosuunnitelmien ja arvosanan yhteyksien tarkastelemiseen.

Logistisen regressioanalyysin tavoitteena oli tarkastella, miten ensiksikin tiettyyn motivaatioprofiiliin kuuluminen yksinään selittää oppilaan jatko-opiskelupaikan valintaa (lukio vs. ammatillinen) ja toiseksi, miten oppilaan kyseisen kielen opiskelustaan saaman arvosanan (4-10) huomioiminen vaikuttaa tähän yhteyteen. Tämän testaamiseksi rakennettiin kaksi logistista regressiomallia. Analyysiä varten profiilit 4 ja 5 vaihdettiin ristiin, jotta profiili 5 (motivoituneimmat) saatiin referenssiryhmäksi (vertailuryhmäksi) profiilin 4 (kielijännittäjät) sijaan. 
Profiilien ja arvosanojen lähempi tarkastelu osoitti, että huonoimmat arvosanat saatiin oletetusti profiilissa 1 eli heikoiten motivoituneiden ryhmässä ja profiilissa 4 eli kielijännittäjienryhmässä. Parhaat arvosanat olivat puolestaan odotetusti motivoituneimmilla oppilailla profiilissa 5 ja myöskin alhaisen kielijännityksen keskivertomotivoituneilla profiilissa 2 . Hieman yllättäen keskivertomotivoituneiden profiilissa 3 oli odotettua enemmän arvosanaa 6 ja vähemmän korkeimpia arvosanoja 9 ja 10.

\subsection{Regressiomalli 1}

Analyysissä lähdettiin liikkeelle mallista, jossa tarkasteltiin ensin pelkästään motivaatioprofiilin ja jatko-opintosuunnitelmien yhteyttä. Jatkosuunnitelmat oli siis selitettävä muuttuja ja profiili selittävä muuttuja. Profiilin 5 oppilaat asetettiin referenssiryhmäksi ja ammatillinen koulutus referenssikategoriaksi. Mallin tuloksista (ks. taulukko 3) voidaan nähdä, että profiileissa 3 (keskivertomotivoituneet; $\mathrm{p}<.05)$ ja 4 (kielijännittäjät; $\mathrm{p}<.05$ ) ammatilliseen koulutukseen (lukion sijaan) aikovien oppilaiden osuus on noin 2,4-2,9-kertainen $(\operatorname{Exp}(B))$ verrattuna oppilaisiin profiilissa 5 (motivoituneimmat). Sen sijaan profiileissa 1 (motivoitumattomimmat) ja 2 (keskivertomotivoituneet alhaisella kielijännityksellä) ei ollut tilastollisesti merkitsevää eroa profiiliin 5 verrattuna. Malli selittää kuitenkin vain noin viisi prosenttia oppilaiden jatkosuunnitelmien valinnasta (Nagelkerke $=, 050$ ).

Taulukko 3. Logistinen regressiomalli 1 motivaatioprofiilien ja jatko-opintosuunnitelmien yhteys.

\begin{tabular}{lllllllll}
\hline & B & S.E. & Wald & df & Sig. & Exp(B) & $\begin{array}{c}\text { 95\% C.I. for Exp(B) } \\
\text { Lower }\end{array}$ & Upper \\
\hline Step 1 PROFIILI & & & 35,387 & 4 &, 000 & & & \\
\hline [motivoitumattomimmat] &,- 051 &, 299 &, 029 & 1 &, 866 &, 951 &, 529 & 1,709 \\
\hline $\begin{array}{l}\text { [keskivertomotivoituneet } \\
\text { alhaisella kielijännityksellä] }\end{array}$ &,- 099 &, 188 &, 277 & 1 &, 599 &, 906 &, 626 & 1,310 \\
\hline [keskivertomotivoituneet] &, 875 &, 196 & 19,944 & 1 &, 000 & 2,398 & 1,634 & 3,520 \\
\hline [ kielijännittäjät] & 1,060 &, 314 & 11,432 & 1 &, 001 & 2,886 & 1,561 & 5,336 \\
\hline Constant & $-1,277$ &, 120 & 104,787 & 1 &, 000 &, 293 & & \\
\hline
\end{tabular}

Nagelkerke R Square $=, 050$

\subsection{Regressiomalli 2}

Ensimmäisen mallin lisäksi rakennettiin toinen malli, johon lisättiin arvosana selittäväksi muuttujaksi ja sallittiin lisäksi motivaatioprofiilin ja arvosanan yhteisvaikutus. Tässä logistisessa regressiomallissa jatko-opintosuunnitelmat asetettiin edelleen selitettäväksi muuttujaksi, mutta nyt sallittiin selittävien muuttujien, eli profiilin ja arvosanan yhdysvaikutus. Yhdysvaikutuksella tarkoitetaan sitä, että profiilin ja jatkosuunnitelmien yhteys riippuu arvosanan tasosta.

Taulukosta 4 nähdään, että kun yhdysvaikutus sallitaan, todennäköisyys kussakin profiilissa mennä lukioon tai ammatilliseen koulutukseen riippuu arvosanasta. Malli selittää vajaat 30 prosenttia oppilaiden jatkosuunnitelmien valinnoista (Nagelkerke $=, 294$ ). Taulukosta 4 nähdään myös, kuinka profiilien omavaikutus on negatiivinen verrattuna profiilin ja arvosanan yhdysvaikutukseen. Arvosana vaikuttaa siihen, millainen jatkosuunnitelma profiileissa valitaan. 
Taulukko 4. Logistinen regressiomalli 2 motivaatioprofiilien yhteys jatko-opintosuunnitelmiin profiilien ja arvosanan yhteisvaikutuksella (interaktiolla).

\begin{tabular}{|c|c|c|c|c|c|c|c|c|}
\hline & \multirow[t]{2}{*}{ B } & & \multirow[t]{2}{*}{ Wald } & \multirow[t]{2}{*}{ df } & \multirow[t]{2}{*}{ Sig. } & \multirow[t]{2}{*}{$\operatorname{Exp}(B)$} & \multicolumn{2}{|c|}{ 95\% C.I. for $\operatorname{Exp}(B)$} \\
\hline & & & & & & & Lower & Upper \\
\hline Step 1 PROFIILI & & & & & & & & \\
\hline [motivoitumattomimmat] & $-6,487$ & 1,941 & 11,169 & 1 & ,001 & 002 & 000 &, 068 \\
\hline $\begin{array}{l}\text { [keskivertomotivoituneet } \\
\text { alhaisella kielijännityksellä] }\end{array}$ & $-4,510$ & 1,506 & 8,961 & 1 & ,003 & 011 & 001 & 211 \\
\hline [keskivertomotivoituneet] & $-3,062$ & 1,609 & 3,621 & 1 & ,057 & 047 & 002 & 1,096 \\
\hline [kielijännittäjät] & $-7,261$ & 1,876 & 14,980 & 1 &, 000 & 001 & 000 & ,028 \\
\hline ARVOSANA & $-1,202$ & 140 & 74,080 & 1 & ,000 & 301 & 229 & ,395 \\
\hline ARVOSANA * PROFIILI & & & 19,072 & 4 & ,001 & & & \\
\hline $\begin{array}{l}\text { ARVOSANA by } \\
\text { [motivoitumattomimmat] }\end{array}$ & 721 & ,259 & 7,741 & 1 & ,005 & 2,056 & 1,237 & 3,417 \\
\hline $\begin{array}{l}\text { ARVOSANA by } \\
\text { [keskivertomotivoituneet } \\
\text { alhaisella ahdistuneisuudella] }\end{array}$ & 497 & , 189 & 6,897 & 1 & ,009 & 1,644 & 1,134 & 2,383 \\
\hline $\begin{array}{l}\text { ARVOSANA by } \\
\text { [keskivertomotivoituneet] }\end{array}$ & 405 & 205 & 3,894 & 1 & ,048 & 1,499 & 1,003 & 2,241 \\
\hline $\begin{array}{l}\text { ARVOSANA by } \\
\text { [kielijännittäjät] }\end{array}$ & 979 & ,244 & 16,075 & 1 & ,000 & 2,662 & 1,649 & 4,295 \\
\hline Constant & 8,728 & 1,138 & 58,842 & 1 & ,000 & 6175,112 & & \\
\hline
\end{tabular}

Kuviosta 1 voidaan puolestaan nähdä todennäköisyydet aikeista mennä lukioon eri profiileilla ja arvosanoilla. Kuvio perustuu edellä selostettuun interaktiomalliin. Kuviosta nähdään, että kun aikomuksena on jatkaa peruskoulun jälkeen lukioon, profiilien 5 (motivoituneimmat) ja 3 (keskivertomotivoituneet) oppilaat tarvitsevat korkeamman arvosanan aikoakseen mennä lukioon verrattuna oppilaisiin muissa profiileissa. Tulosten perusteella näyttää lisäksi siltä, että profiilin 1 (motivoitumattomimmat) oppilaat suuntaavat lukioon heikommilla arvosanoilla, kuin muiden profiilien oppilaat. Voitaneen myös ajatella, että motivoitumattomilla on lähtökohtaisesti heikommat arvosanat kuin motivoituneilla, ja se näkyy myös näissä tutkimustuloksissa. 


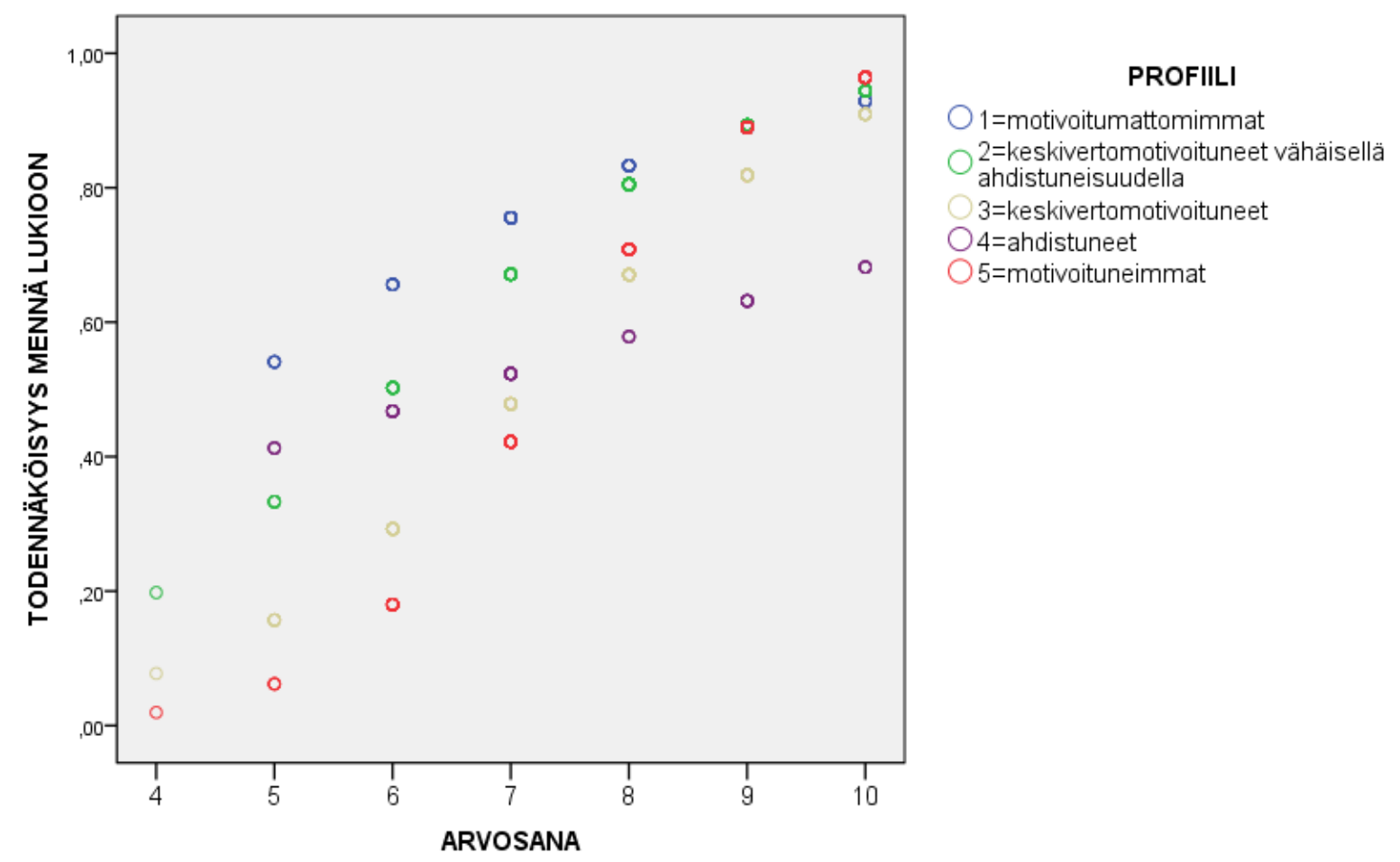

Kuvio 1. Todennäköisyydet mennä lukioon eri profiileilla ja arvosanoilla.

\section{Johtopäätökset ja pohdinta}

Tässä artikkelissa selvitin yhdeksäsluokkalaisten vieraan kielen oppimismotivaatioprofiilien, kielten arvosanojen ja peruskoulun jälkeisten jatko-opiskelusuunnitelmien välisiä yhteyksiä. Tutkimuksen tuloksista käy ilmi, että vieraan kielen opiskelusta saatu arvosana vaikuttaa siihen, kuinka todennäköisesti tutkimuksessa aiemmin löydetyissä (Kangasvieri, 2019) eri vieraan kielen oppimismotivaatioprofiileissa aiotaan jatkaa perusopetuksen jälkeen joko lukioon tai ammatilliseen koulutukseen. Rakennettu malli selittää noin kolmasosan oppilaiden tekemistä koulutusvalinnoista, joten arvosanan vaikutusta voidaan pitää merkittävänä. Motivoituneimmat kokevat korkean arvosanan tärkeämmäksi jatko-opintoja suunnitelleessaan kuin vähemmän motivoituneet. Tämä antaakin aihetta vakavasti pohtia, kuinka vaativana lukiokoulutus näyttäytyy yhdeksäsluokkalaisten silmissä (ks. esim. SKL, 2021a, 2021b).

Artikkelissa raportoidun tutkimuksen pohjalta näyttää siltä, että motivoituneimmat ja myöskin keskivertomotivoituneet kielenoppijat kokevat tarvitsevansa korkeamman arvosanan kuin heikommin motivoituneet oppilaat tehdäkseen päätöksen jatkaa peruskoulun jälkeen lukioon.

Miksi oppilaat, joilla on korkea motivaatio vaativat itseltään korkeampaa arvosanaa, että kokevat voivansa jatkaa lukioon? Mikä yhtäältä synnyttää niin sanotuissa hyvissä oppilaissa kokemuksen, että arvosanan täytyy olla vieraassa kielessä korkea, jotta voi jatkaa opintoja lukiossa, ja toisaalta aikaansaa sen, että vieraassa kielessä huonomman arvosanan saaneet motivoitumattomimmat oppilaat aikovat jatkaa suuremmalla todennäköisyydellä lukioon, kuin nämä kieliopinnoissaan motivoituneet oppilaat? Voisiko olla, että kieltenopiskeluun motivoituneimmat oppilaat myös vaativat itseltään enemmän, eli tässä tapauksessa korkeampaa 
arvosanaa, jotta päättäisivät suunnata lukioon? Vai onko heikommin motivoituneilla, mutta lukioon aikovilla käytössään muita, esimerkiksi perheeseen liittyviä resursseja, joiden turvin he ponnistavat lukiokoulutukseen?

Motivoituneimpien profiilissa muutamat oppilaat näkivät selkeimmin kieltenopiskelusta koituvan (jopa taloudellisen) hyödyn ja statusarvon ja haluavat oppia paljon kieliä, joten heidän voikin olettaa jatkavan lukiokoulutukseen. Kyseiset oppilaat toteavat kyselyssä esimerkiksi näin:

(6) Kielten opiskelu kannattaa. (tyttö, A1-englanti)

(7) kielten opiskelu on tärkeää, jos lähtee ulkomaille!! (tyttö, B2-ranska)

(8) Kielten opiskelu ja osaaminen on hyödyllistä melkein joka ammattia ajatellen. (tyttö, B2-ranska)

(9) Suurin syy siihen, että haluan opiskella ahkerasti kieliä on, että pääsisin joskus tulevaisuudessa käyttämään opittuja kieliä esim. työssäni. Suurin haaveeni on valmistua tulkiksi (mieluiten englannin tulkiksi). (tyttö, B2-saksa)

Tämän tutkimuksen tulosten perusteella on havaittavissa viitteitä siltä, että lukiokoulutus näyttäytyy peruskoululaisille todella vaativana opinahjona. Ei siis ihme, että tämän päätöksen tehdäkseen oppilas vaatii itseltään myös korkeaa arvosanaa kieliopinnoissaan. Sen sijaan motivoitumattomimmat kieltenopiskeluun mielenkiintonsa pysyvästi menettäneet "ihan sama" -tyypit aikovat lukiokoulutukseen huonommillakin arvosanoilla. He ehkä koettavatkin vain onneaan, että pääsisivätkö lukiokoulutukseen. Toki myös lukioiden välillä on paikkakunnittain ja lukioittain suuria eroja siinä, millaisella perusopetuksen päättötodistuksen keskiarvolla niihin pääsee opiskelemaan (Hotulainen ym., 2016).

Ainakin tutkimuksen pohjalta voidaan todeta, ettei korkea motivaatio kieliopinnoissa yksistään riitä suuntaamaan nuorta lukioon tai heikko motivaatio ammatilliseen koulutukseen, vaan myös koulumenestyksellä kieliopinnoissa on vaikutusta koulutusvalintaan.

Tutkimukseni pohjalta ei voi olettaa, että pelkkä kouluarvosana (hyvä tai huono) joko motivoi tai ei motivoi oppilaita kieltenopiskeluun. Sen sijaan tutkimuksestani käy ilmi, että jo yläkouluikäiset osaavat arvioida kieltenopiskelun hyödyllisyyttä ja kielten tarvetta myöhemmin elämässä.

Oppilaiden motivaation puute voi mahdollisesti johtua myös siitä, että kieltenopiskelu koulussa ei motivoi (ks. myös KARVI, 2013). Kieliä, erityisesti englantia, opitaan nykyään hyvin paljon koulun ulkopuolella (ks. esim. Mustaparta, 2015; Härmälä ym. 2018), eivätkä koulumaailman (opettajien, pedagogiikan) ja oppilaiden maailmat tässä enää kohtaa. Tässä onkin paljon jatkotutkimuksen aihetta.

Tässäkin tutkimuksessa lukioon aikovista oppilaista enemmistö oli tyttöjä. Tytöt vaativat itseltään enemmän ja heidän tavoitteensa kielten opiskelussa ovat korkeammalla. Kielen arvosanan pitää olla korkeampi, jotta he voivat mennä lukioon, jossa kieliopinnot ovat tärkeämmässä roolissa kuin ammatillisessa koulutuksessa, kuten artikkelissa aiemmin totesin.

Tutkimuksen tuloksia arvioidessa on kuitenkin hyvä pitää mielessä, että kyse oli yhdeksäsluokkalaisten aikomuksesta, eikä lopullisesta valinnasta perusopetuksen jälkeisten opintojen suhteen. Ei siis voida tietää, moniko oppilaista jatkoi oikeasti lukiokoulutukseen ja kuinka moni ammatilliseen koulutukseen.

Perusopetuksessa päättöarviointi annetaan kuitenkin edelleen numeerisena, mikä voi osaltaan olla vaikuttamassa oppilaiden jatkosuunnitelmiin, kuten tämän tutkimuksen tulokset osoittavat vieraiden kielten opiskelun osalta. Tämän tutkimuksen tulosten perusteella on todennäköisimmin niin, että lukiokoulutukseen hakeutuminen edellyttää sekä korkeaa motivaatiota että kouluarvosanoin mitattuna hyvää koulumenestystä. 
Tutkimukseni rajoituksina voidaan pitää ensinnäkin sitä, että selvä enemmistö $(60,7 \%)$ tutkituista oppilaista oli aikeissa jatkaa lukioon, ja toiseksi, hyvät arvosanat painottuivat kieltenopiskeluun motivoituneimpien profiilissa, joitta oli lukioon aikovissa 39 \%. Tutkimus antaa kuitenkin aihetta pohtia, millä tavalla arviointi on yhteydessä kielenoppimismotivaatioon. Voiko olla niin, että kouluarvosanan rooli on motivaatiota suurempi, ja mitä tämä tarkoittaa kielikoulutuspolitiikan näkökulmasta? Ja voitaisiinko parempaa motivaatiota ja parempia oppimistuloksia kieltenopiskelussa saavuttaakin keskittymällä arviointiin ja uudistamalla sitä, eikä turhaan koulutuspolitikoimalla motivaatiolla (ks. esim. OKM, 2015; Rautopuro \& Juuti, 2018; YLE, 2014)? Uusimmissa opetussuunnitelman perusteissa $(\mathrm{OPH}, 2014)$ painotetaan nimenomaan formatiivista, oppimista tukevaa arviointia useimmiten etualalle pääsevän summatiivisen, numeerisen arvioinnin sijaan. Tässä artikkelissa raportoitujen tulosten perusteella vaikuttaa ainakin jossain määrin siltä, että arviointi on motivaatioprofiileja merkittävämpi tekijä jatkoopintosuunnitelmia tehtäessä.

Koska osaaminen ja motivaatio liittyvät toisiinsa, osaamisen lisääntyminen kohonneella arvosanalla mitattuna todennäköisesti lisää myös motivaatiota. Panostukset formatiiviseen arviointiin ovatkin varmasti paikallaan oppilaiden motivaatiota ajatellen.

Lisäksi on syytä vakavasti pohtia koulutusvalintojen problematiikkaa ja kieliopintojen roolia siinä, ettei tilanne eskaloidu siihen, että lukiokoulutus on tulevaisuudessa ensisijaisesti korkeakoulutettujen vanhempien jo perusopetuksessa kieliä opiskelleiden lasten opinahjo. Emme kai halua rapauttaa suomalaista tasaarvoista ja yhdenvertaista koulutusjärjestelmäämme tällä tavoin?

Tämä tutkimus antaa lisäksi voimakkaasti aihetta pohtia, miten nuoret voisivat hankkia enemmän valmiuksia tehdä perusteltuja ja motivoivia toisen asteen koulutusvalintoja. Kieltenopiskelu on toki vain yksi pieni, vaikkakin nykymaailmassa tärkeä tekijä tämän koulutusvalinnan yhteydessä. Tärkeintä on, että kaikki nuoret löytävät oman motivoivan koulutuspolkunsa, sillä tämä edistää sosiaalista ja koulutuksellista tasa-arvoa ja tasavertaisuutta maassamme. 


\section{Kiitokset}

Haluan kiittää henkilökohtaisia avustajiani Leena Polenovia ja Kristiina Siekkistä kaikesta avusta tämän artikkelikäsikirjoituksen työstämisessä.

\section{Loppuviite}

${ }^{1}$ High stakes -testillä tarkoitetaan ns. korkean panoksen testiä, jonka seuraukset ovat merkittäviä testattavalle, kuten esim. ylioppilastutkinnon kokeet Suomessa (ks. esim. YTL, 2013).

\section{Lähteet}

Al-Hoorie, A., \& Macintyre, P. (toim.) (2020). Contemporary language motivation theory: 60 years since Gardner and Lambert (1959). Multilingual Matters.

Beacco, J.-C. (2007). From linguistic diversity to plurilingual education: Guide for the development of language education policies in Europe. Language Policy Division Strasbourg: Council of Europe.

Boo, Z., Dörnyei, Z., \& Ryan. S. (2015). L2 motivation research 2005-2014: Understanding a publication surge and a changing landscape. System 55, 145-157. https://doi.org/10.1016/ j.system.2015.10.006

Dörnyei, Z. (1990). Conceptualizing motivation in foreign language learning. Language Learning, 40(1), 45-78. https:// doi.org/10.1111/j.1467-1770.1990.tb00954.x

Dörnyei, Z. (1994). Motivation and motivating in the foreign language classroom. Modern Language Journal, 78(3), 273-84. http://www.jstor.org/stable/330107

Dörnyei, Z. (2001). Teaching and researching motivation. Longman.

Dörnyei, Z., \& Ottó, I. (1998). Motivation in action: A process model of L2 motivation. Working Papers in Applied Linguistics, Thames Valley University, 4, 43-69.

Dörnyei, Z., \& Ushioda, E. (toim.) (2009). Language identity and the L2 self. Multilingual Matters.

Dörnyei, Z., \& Ushioda, E. (toim.) (2011). Teaching and researching motivation (2nd ed). Longman.

Dörnyei, Z., MacIntyre, P. D., \& Henry, A. (2015). Introduction: Applying complex dynamic systems principles to empirical research on L2 motivation. Teoksessa Z. Dörnyei, P. D. MacIntyre \& A. Henry (toim.), Motivational dynamics in language learning (s. 1-7). Multilingual Matters.

Dörnyei, Z., Henry, A., \& Muir, C. (2016). Motivational currents in language learning: Frameworks for focused interventions. Routledge.

European Commission (2007). High level group on multilingualism. Final report, Commission of the European Communities.

Eddington, D. (2015). Statistics for linguists: A step-by-step guide for novices. Cambridge Scholars Publishing.

Gardner, R. C. (1985). Social psychology and second language learning: The role of attitudes and motivation. Edward Arnold.

Gardner, R. C. (2004). Attitude/Motivation test battery. International AMTB research project. The University of Western Ontario.

Geber, E. (2010). Den obligatoriska svenskan i Finland - en historisk analys Magma pm 1. Finlands svenska tankesmedja Magma.

Gellman, A., \& Hill, J. (2007). Data analysis using regression and multilevel/hierarchical models. Cambridge University Press.

Harinen, P., Laitio, T., Niemivirta, M., Nurmi, J.-E., \& Salmela-aro, K. (2015). Oppimismotivaatio, kouluviihtyvyys ja hyvinvointi. Teoksessa N. Ouakrim-Soivio, A. Rinkinen \& T. Karjalainen (toim.), Tulevaisuuden peruskoulu (s. 66-75). Opetus- ja kulttuuriministeriön selvityksiä 2015:8. Opetus- ja kulttuuriministeriö. 
Harlen, W. (2012). The role of assessment in developing motivation for learning. Teoksessa J. Gardner (toim.), Assessment and learning (s. 171-184). Sage Publications.

Harlen, W., \& Crick, R. D. (2003). Testing and motivation for learning. Assessment in education: Principles, Policy \& Practice, 10(2), 169-207. https://doi.org/10.1080/09695 94032000121270

Hilden, R., \& Takala, S. (2007). Relating descriptors of the Finnish school scale to the CEF overall scales for communicative activities. Teoksessa A. Koskensalo, J. Smeds, P. Kaikkonen, \& V. Kohonen (toim.), Foreign languages and multicultural perspectives in the European context $=$ Fremdsprachen und multikulturelle perspektiven im europäischen kontex (s. 91-300). LIT Verlag.

Hildén, R. \& Rautopuro, J. (2014a). Saksan kielen A- ja B-oppimäärän oppimistulokset perusopetuksen päättövaiheessa 2013. Julkaisut 2014:4. Kansallinen koulutuksen arviointikeskus ja Opetushallitus.

Hildén, R., \& Rautopuro, J. (2014b). Ruotsin kielen A-oppimäärän oppimistulokset perusopetuksen päättövaiheessa 2013. Julkaisut 2014:1. Kansallinen koulutuksen arviointikeskus ja Opetushallitus.

Hildén, R., \& Rautopuro, J. (2014c). Venäjän kielen A- ja B-oppimäärän oppimistulokset perusopetuksen päättövaiheessa 2013. Julkaisut 2014:5. Kansallinen koulutuksen arviointikeskus ja Opetushallitus.

Hotulainen, R., Rimpelä, A., Karvonen, S. Kupiainen, S., Lindfors P., Kinnunen, J. M., Minkkinen, J., Vainikainen, M-P., \& Wallenius, T. (2016). Metropolialueen nuorten siirtyminen yläkoulusta toiselle asteelle: Osaaminen ja hyvinvointi. Valtioneuvoston selvitysja tutkimustoiminnan julkaisusarja 27/2016. Valtioneuvoston kanslia.

Hurskainen, M., \& Ylönen, S. (2015). Vieraiden kielten oppimismotivaatio: Esimerkkinä saksa yliopisto-opiskelijoiden keskuudessa. Teoksessa T. Jakonen, J. Jalkanen, T. Paakkinen \& M. Suni (toim.), Kielen oppimisen virtauksia. Flows of language learning (s. 73-90). Suomen soveltavan kielitieteen yhdistyksen julkaisuja no. 73 .

Härmälä, M., \& Huhtanen, M. (2014). Ranskan kielen A- ja B-oppimäärän oppimistulokset perusopetuksen päättövaiheessa 2013. Julkaisut 2014:3. Kansallinen koulutuksen arviointikeskus ja Opetushallitus.

Härmälä, M., Huhtanen, M., \& Puukko, M. (2014). Englannin kielen A-oppimäärän oppimistulokset perusopetuksen päättövaiheessa 2013. Julkaisut 2014:2. Kansallinen koulutuksen arviointikeskus ja Opetushallitus.

Härmälä, M., Leontjev, D., \& Kangasvieri, T. (2017). Relationship between students' opinions, background factors and learning outcomes: Finnish 9th graders learning English. International Journal of Applied Linguistics, 27(3), 665-681. https://doi.org/10.1111/ ijal.12172

Härmälä, M., Huhtanen, M., Puukko, M., \& Marjanen, J. (2018). A-englannin oppimistulokset 7. luokan alussa 2018. Julkaisut 13:2019. Kansallinen koulutuksen arviointikeskus KARVI.

Julkunen, K. (1989). Situation- and task-specific motivation in foreign-language learning and teaching. Joensuun yliopiston kasvatustieteellisiä julkaisuja no. 6. University of Joensuu.

Julkunen, K. (1998a). Vieraan kielen oppiminen: A2-kielen opiskelijoiden motivaatio ja kielen valintaan vaikuttaneet tekijät. Research reports of the Faculty of Education no. 70. Joensuun yliopisto.

Julkunen, K. (1998b). Vieraan kielen oppiminen: A2-kielen opiskelijoiden oppimisstrategiat ja opiskelun kokeminen. Research reports of the Faculty of Education no. 73. Joensuun yliopisto.

Julkunen, K., \& Borzova, H. (1997). English Language Learning Motivation in Joensuu and Petrozavodsk. Research reports of the Faculty of Education no. 64. University of Joensuu.

Juurakko-Paavola, T., \& Palviainen, Å. (toim.) (2011). Svenskan i den finska skolan och högre utbildningen: Om kunskaper och motivation genom olika utbildningsstadier. HAMKin julkaisuja, 11/2011. Hämeen ammattikorkeakoulu.

Kalalahti, M., Zacheus, T., Laaksonen, L. M., \& Jahnukainen, M. (2019). Toiselle asteelle ja eteenpäin: Eriytyvät toisen asteen koulutuspolut. Teoksessa M. Jahnukainen, M. Kalalahti \& J. Kivirauma (toim.), Oma paikka haussa: Maahanmuuttotaustaiset nuoret ja koulutus (s. 71-89). Gaudeamus University Press. 
Kangasvieri, T., Miettinen, E., Kukkohovi, P., \& Härmälä, M. (2011). Kielten tarjonta ja kielivalintojen perusteet perusopetuksessa. Muistiot 2011: 3. Opetushallitus.

Kangasvieri, T. (2019). L2 motivation in focus: the case of Finnish comprehensive school students. Language Learning Journal, 47(2), 188-203. https://doi.org/10.1080/09571736. $\underline{2016.1258719}$

Kangasvieri, T. (hyväksytty julkaistavaksi). No en mie sitä voinu valita pakkoha sitä on opiskella" - Perus-asteen yläkoulun oppilaiden kielivalintoihin vaikuttavat tekijät.

Kantelinen, R., \& Kettunen, S. (toim.) (2004). Ruotsin kielen opiskelumotivaatiosta yleissivistävässä ja ammatillisessa koulutuksessa. Kasvatustieteiden tiedekunnan tutkimuksia no. 89. Joensuun yliopisto.

KARVI (2013). Kielten oppimistulokset perusopetuksen päättövaiheessa. Informaatioaineistot 2014:1. Kansallinen koulutuksen arviointikeskus ja Opetushallitus.

KARVI (2020). Vaihtoehtoja, valintoja ja uusia alkuja - Arviointi nuorten opintopoluista ja ohjauksesta perusopetuksen ja toisen asteen nivelvaiheessa. Julkaisut 6:2020. Kansallinen koulutuksen arviointikeskus.

Kovanen, J. (2004). Ruotsin kielen opiskelumotivaatiosta peruskoulussa. Teoksessa R. Kantelinen \& S. Kettunen (toim.), Ruotsin kielen opiskelumotivaatiosta yleissivistävässä ja ammatillisessa koulutuksessa (s. 43-52). Kasvatustieteiden tiedekunnan tutkimuksia no. 89. Joensuun yliopisto.

Kosunen, S. (2016). Families and the social space of school choice in urban Finland. Institute of Behavioural Sciences, Studies in Educational Sciences 267. University of Helsinki.

Kumpulainen, T. (toim.) (2014). Koulutuksen tilastollinen vuosikirja 2014 - Årsbok för utbildningsstatistik 2014. Koulutuksen seurantaraportit 2014:10. Opetushallitus.

Kupari, P., Välijärvi, J., Andersson, L., Arffman, I., Nissinen, K., Puhakka, E., \& Vettenranta, J. (2013). PISA12 ensituloksia. Opetus- ja kulttuuriministeriön julkaisuja 2013:20. Opetus- ja kulttuuriministeriö.

Kupiainen, S. (2016a). Toisen asteen valinta. Teoksessa R. Hotulainen, A. Rimpelä, S., Karvonen, S. Kupiainen, P. Lindfors, J. M. Kinnunen, J. Minkkinen, M-P. Vainikainen \& T. Wallenius (toim.), Metropolialueen nuorten siirtyminen yläkoulusta toiselle asteelle: Osaaminen ja hyvinvointi (s. 59-63). Valtioneuvoston selvitys- ja tutkimustoiminnan julkaisusarja 27/2016. Valtioneuvoston kanslia.

Kupiainen, S. (2016b). Päättöarvosanojen ennustaminen. Teoksessa R. Hotulainen, A. Rimpelä, S. Karvonen, S. Kupiainen, P. Lindfors, J. M. Kinnunen, J. Minkkinen, M-P. Vainikainen, \& T. Wallenius (toim.), Metropolialueen nuorten siirtyminen yläkoulusta toiselle asteelle: Osaaminen ja hyvinvointi (s. 25-29). Valtioneuvoston selvitys- ja tutkimustoiminnan julkaisusarja 27/2016. Valtioneuvoston kanslia.

Kyllönen, T., \& Saarinen, T. (2010). Kielikoulutuspolitiikkaa kunnissa. Kieli, koulutus ja yhteiskunta, 1(4). https://www.kieliverkosto.fi/fi/journals/kieli-koulutus-ja-yhteiskuntaelokuu-2010/kielikoulutuspolitiikkaa-kunnissa

Lahtinen J. (toim.) (2019)."Mikä ois mun juttu" - nuorten koulutusvalinnat sosialisaatiomaisemien kehyksissä. Valtioneuvostonselvitys- ja tutkimustoiminnan julkaisusarja 2019:68. Valtioneuvoston kanslia.

Lamb, M., Csizér, K., Henry, A., \& Ryan, S. (toim.) (2019). The Palgrave handbook of motivation for language learning. Palgrave Macmillan.

Leppänen, S., Pitkänen-Huhta, A., Nikula, T., Kytölä S., Törmäkangas T., Nissinen K., Kääntä L., Virkkula T., Laitinen M., Pahta P., Koskela H., Lähdesmäki S., \& Jousmäki H. (2009). Kansallinen kyselytutkimus englannin kielestä Suomessa Käyttö, merkitys ja asenteet. Jyväskylä Studies in Humanities 132. Jyväskylän yliopisto.

Mattila, M. (toim.) (2020). Eriarvoisuuden tila Suomessa 2020. Kalevi Sorsa -säätiö.

Murray, G., Gao, X., \& Lamb, T. (toim.) (2011). Identity, motivation and autonomy in language learning. Multilingual Matters.

Mustaparta, A.-K. (toim.) (2015). Kieli koulun ytimessä - näkökulmia kielikasvatukseen. Oppaat ja käsikirjat 2015:15. Opetushallitus.

Nikki, M.-L. (1992). Suomalaisen koulutusjärjestelmän kielikoulutus ja sen relevanssi. Osa II. Jyväskylä Studies in Education, Psychology and Social Research 86. Jyväskylän yliopisto. 
Opetus- ja kulttuuriministeriö (2015). Millä eväillä osaaminen uuteen nousuun? PISA 2012 tutkimustuloksia. Opetus- ja kulttuuriministeriön julkaisuja 2015:6. Opetus- ja kulttuuriministeriö.

Opetus- ja kulttuuriministeriö (2018). Valtioneuvosto päätti peruskoulun tuntimäärän kasvattamisesta - kieltenopetus alkaa jatkossa jo ensimmäiseltä luokalta. Opetus- ja kulttuuriministeriön tiedote 20.9.2018. https://minedu.fi/artikkeli/-/asset_publisher/valtioneuvosto-paatti-peruskoulun-tuntimaaran-kasvattamisesta-kieltenopetus-alkaa-jatkossa-jo-ensimmaiselta-luokalta

Opetus- ja kulttuuriministeriö (2020a). Oppivelvollisuuden laajentaminen. Opetus- ja kulttuuriministeriö. Hankkeet ja säädösvalmistelu. https://minedu.fi/oppivelvollisuuden-laajentaminen

Opetus- ja kulttuuriministeriö (2020b). Oppivelvollisuus laajenee elokuussa 2021 - edellytyksiä nuorten oppimiseen ja hyvinvointiin parannetaan, työllisyysastetta nostetaan. Opetus- ja kulttuuriministeriön tiedote 15.10.2020. https://okm.fi/-/oppivelvollisuus-laajeneeelokuussa-2021-edellytyksia-nuorten-oppimiseen-ja-hyvinvointiin-parannetaan-tyollisyysastetta-nostetaan

Opetushallitus (2014). Perusopetuksen opetussuunnitelman perusteet 2014. Määräykset ja ohjeet 2014:96. Opetushallitus.

Opetushallitus (2017). ePerusteet 2016. https://eperusteet.opintopolku.fi/\#/fi/selaus/ammatillinenperuskoulutus

Opetushallitus (2019a). Faktaa Express 1A/2019. Mitä kieliä perusopetuksessa opiskellaan? Tilastotietoa oppilaiden kielten opiskelusta ja kielivalinnoista. Opetushallitus.

Opetushallitus (2019b). Lukion opetussuunnitelman perusteet 2019. Määräykset ja ohjeet 2019:2a. Opetushallitus.

Opetushallitus (2020a). Arviointi peruskouluissa yhdenmukaistuu - arviointiluvunmuutoksilla parannetaan oppilaiden yhdenvertaisuutta Suomessa. Opetushallitus.

Opetushallitus (2020b). Oppilaan oppimisen ja osaamisen arviointi perusopetuksessa perusopetuksen opetussuunnitelman perusteiden 2014 muutokset. Opetushallitus.

Opetushallitus (2020c). Perusopetuksen päättöarvioinnin kriteerit. Opetushallituksen määräys OPH-5042-2020. Opetushallitus.

Peng, C.-Y. J., Lee, K. D., \& Ingersoll, G. M. (2002). An introduction to logistic regression analysis and reporting. The Journal of Educational Research, 96(1), 3-14. https://doi.org/10. $1080 / 00220670209598786$

Pihko, M.-K. (2009). "Pahinta on omin sanoin sanominen" Kielijännitys tavanomaisessa vieraan kielen opetuksessa ja vieraskielisessä sisällönopetuksessa. Kasvatus, 40(1), 60-68.

Piri, R. (2001). Suomen kieliohjelmapolitiikka: Kansallinen ja kansainvälinen toimintaympäristö. Väitöskirja. Jyväskylän yliopisto: Soveltavan kielentutkimuksen keskus.

Pyykkö, R. (2017). Monikielisyys vahvuudeksi. Selvitys Suomen kielivarannon tilasta ja tasosta. Opetus- ja kulttuuriministeriön julkaisuja 2017:51. Opetus- ja kulttuuriministeriö

Rautopuro J., \& Juuti, K. (toim.) (2018). PISA pintaa syvemmältä - PISA 2015 Suomen pääraportti. Kasvatusalan tutkimuksia 77 . Suomen kasvatustieteellinen seura.

Suomen Kuvalehti. (2021a). Kotro, A. Lukio meni rikki. Suomen Kuvalehti 12.3.2021.

Suomen Kuvalehti. (2021b). Kalliokoski, M. Aikuiseksi painekattilassa. Suomen kuvalehti 18.3.2021.

Salmela-Aro, K., Kiuru, N., \& Nurmi, J.-E. (2008). The role of educational track in adolescents' school burnout: A longitudinal study. British Journal of Educational Psychology, 78, 663-689. https://doi.org/10.1348/000709908X281628

Tilastokeskus (2019a). Peruskoulun 9. luokan päättäneiden välitön hakeminen jatko-opintoihin, 2000-2018. Tilastokeskuksen PX-Web -tietokannat.

Tilastokeskus (2019b). Peruskoulun oppilaiden ainevalinnat 2018. Tilastokeskus http://www.stat. fi/til/ava/2018/02/ava_2018_02_2019-05-23_tie_001_fi.html

Tilastokeskus (2020). Peruskoulun oppilaiden ainevalinnat 2019. Tilastokeskus: http:/ /www.stat. fi/til/ava/2019/02/ava_2019_02_2020-05-20_tie_001_fi.html

Tollefson, J. W., \& Tsui, A. B. M. (2014). Language diversity and language policy in educational access and equity. Review of Research in Education, 38(1), 189-214. https://doi.org/ $\underline{10.3102 / 0091732 X 13506846}$

Tuominen-Soini, H., Salmela-Aro, K., \& Niemivirta, M. (2012). Achievement goal orientations and academic wellbeing across the transition to upper secondary education. Learning and Individual Differences, 22(3), 290-305. https://doi.org/10.1016/i.lindif.2012.01.002 
Tuononen, M., \& Vanhalakka-Ruoho, M. (toim.) (2016). Ammatilliseen vai lukioon: Nuoren suunnanottoja perheen kehystämänä. Publications of the University of Eastern Finland. Reports and Studies in Education, Humanities, and Theology no. 14. Itä-Suomen yliopisto.

Ullakonoja, R., Nieminen, L., \& Huhta, A. (2013). Suomen kielen oppimismotivaatio, luetunymmärtäminen ja kirjoitustaito venäjää kotikielenään puhuvilla peruskoululaisilla. Kasvatus, 5, 508-521.

Ushioda, E. (2013). Motivation and ELT: Global issues and local concerns. Teoksessa E. Ushioda (toim.), International perspectives on motivation: Language learning and professional challenges (s. 1-17). Palgrave Macmillan.

Vasalampi, K., Nurmi, J.-E., \& Salmela-Aro, K. (2010). Sisäisen motivaation ja hyvinvoinnin rooli onnistuneessa koulutussiirtymässä. Psykologia, 45(05-06), 402-411.

Vasalampi, K., \& Salmela-Aro, K. (2014). Sisäinen motivaatio ja kouluinnokkuus edistävät nuorten opintopolkuja. Teoksessa S. Pihlajaniemi, T. Villa, E. Lavikainen \& L. Valkeasuo (toim.), Oppia ikä kaikki - kouluttautumisen edellytykset eri elämänvaiheissa. Opiskelijatutkimuksen vuosikirja (s. 12-23). Opiskelun ja koulutuksen tutkimussäätiö Otus.

Välijärvi, J., Kupari, P., Ahonen, A. K., Arffman, I., Harju-Luukkainen, H., Leino, K., Niemivirta, M., Nissinen, K., Salmela-Aro, K., Tarnanen, M., Tuominen-Soini, H., Vettenranta, J., \& Vuorinen, R. (2015). Millä eväillä osaaminen uuteen nousuun? PISA 2012 -tutkimustuloksia. Opetus- ja kulttuuriministeriön julkaisuja 2015:6. Opetus- ja kulttuuriministeriö.

YLE (2014, huhtikuu). PISA-asiantuntija: Oppilaiden motivointi on avainkysymys. YLE uutiset. https://yle.fi/uutiset/3-7166900

YTL (2013). Korkean panoksen sähköiset kokeet maailmalla. Digabi-projektin työpaperi. Ylioppilastutkintolautakunta. 
LIITE 1. Esimerkkejä oppilaskyselyn väittämistä., joihin oppilaat vastasivat Likertin asteikolla 5 Pitää täysin paikkansa - 1 Ei pidä ollenkaan paikkaansa.

Tämän kielen opiskelu on tärkeää, koska siitä voi olla apua tulevassa ammatissani.

Haluan oppia tuntemaan tätä kieltä puhuvia ihmisiä ja heidän kulttuuriaan paremmin. Opiskelen mielelläni tätä kieltä.

Käytän mielelläni tätä kieltä erilaisissa käytännön tilanteissa, kuten esimerkiksi neuvon vieraskielisille turisteille tietä.

Olen todella hyvä tässä kielessä.

Tämän kielen tunnilla ei tarvitse jännittää tai tuntea itseään ahdistuneeksi.

Pidän todella tämän kielen opettajastani.

Tämän kielen opettajallani on innostava ja mielenkiintoinen tyyli opettaa oppilaita. Ystävieni mielestä tämän kielen opiskelu on tärkeää.

Vanhempani yrittävät auttaa minua oppimaan tätä kieltä. 